\title{
Bone status in adolescents with type 1 diabetes
}

\author{
A. P. Chobot • A. Haffke • J. Polanska • Z. P. Halaba • \\ G. Deja $\cdot$ P. Jarosz-Chobot $\cdot$ W. Pluskiewicz
}

Received: 10 January 2010 / Accepted: 31 March 2010/Published online: 9 May 2010

(C) Springer-Verlag 2010

\begin{abstract}
Aims The aim of the study was to investigate the potential negative impact of type 1 diabetes on bone status of adolescents. Bone status in adolescents with type 1 diabetes was assessed by means of quantitative ultrasound (QUS) and the influence of metabolic control and other diseaserelated and growth variables was analysed.

Methods Group I consisted of 99 pubertal (Tanner $\geq 2$ ) adolescents (49 female), aged $14.3 \pm 2.5$ years, diabetes duration $4.6 \pm 2.3$ years. Controls (group II) were 297 children, matched by sex and age, from a healthy population. The influence of glycated haemoglobin (cur-
\end{abstract}

\footnotetext{
A. P. Chobot $(\triangle)$

Department of Paediatrics, Clinical Hospital No. 1,

3-go Maja 13-15,

41-800 Zabrze, Poland

e-mail: pjarosz-chobot@sum.edu.pl

\section{A. Haffke}

Hegau-Jugendwerk,

Gailingen am Hochrhein, Germany

J. Polanska

System Engineering Group, Silesian University of Technology,

Gliwice, Poland
}

\section{Z. P. Halaba}

Department of Obstetrics and Gynaecology,

Specialist Hospital No. 2,

Bytom, Poland

G. Deja $\cdot$ P. Jarosz-Chobot

Department of Paediatrics, Endocrinology and Diabetes,

Medical University of Silesia,

Katowice, Poland

W. Pluskiewicz

Metabolic Bone Diseases Unit, Medical University of Silesia,

Katowice, Poland rent: $\mathrm{HbA}_{1 \mathrm{c}} \mathrm{D}$; last year's mean: $\mathrm{HbA}_{1 \mathrm{c}} \mathrm{Y}$; whole duration mean: $\mathrm{HbA}_{1 \mathrm{c}} \mathrm{T}$ ), diabetes duration, percentage of life with disease and daily insulin requirement (DIR) on amplitude dependent speed of sound (Ad-SoS) at distal phalanges was studied.

Results In comparison to the control group, adolescents with type 1 diabetes presented significantly higher BMI SDS $(0.82$ [95\% CI $0.54,1.10]$ vs -0.06 [95\% CI -0.16 , $0.04] p<0.001)$ and lower Ad-SoS SDS $(-0.34[95 \%$ CI $-0.57,-0.11$ ] vs -0.03 [95\% CI $-0.15,0.08$ ], $p<0.05)$. No correlation between Ad-SoS SDS and sex, DIR or diabetes duration was observed. The lower Ad-SoS SDS reflects reduced bone status, and the reduction was significantly more marked in those patients whose $\mathrm{HbA}_{1 \mathrm{c}} \mathrm{T}$ was higher than $7.0 \%$ when compared with those whose $\mathrm{HbA}_{1 \mathrm{c}} \mathrm{T}$ was lower.

Conclusions Bone status of adolescents with type 1 diabetes mellitus assessed with QUS differs from that of healthy peers and is dependent on long-term metabolic control.

Keywords Adolescence $\cdot \mathrm{HbA}_{1 \mathrm{c}}$. Quantitative ultrasound Type 1 diabetes

\begin{tabular}{|c|c|}
\hline \multicolumn{2}{|c|}{ Abbreviations } \\
\hline Ad-SoS & Amplitude dependent speed of sound \\
\hline BMD & Bone mineral density \\
\hline DIR & Daily insulin requirement \\
\hline DKA & Diabetes ketoacidosis \\
\hline $\mathrm{HbA}_{1 \mathrm{c}} \mathrm{D}$ & $\mathrm{HbA}_{1 \mathrm{c}}$ at the day of study \\
\hline $\mathrm{HbA}_{1 \mathrm{c}} \mathrm{T}$ & $\begin{array}{l}\text { Mean } \mathrm{HbA}_{1 \mathrm{c}} \text { from the whole duration } \\
\text { of diabetes }\end{array}$ \\
\hline $\mathrm{HbA}_{1 \mathrm{c}} \mathrm{Y}$ & Mean $\mathrm{HbA}_{1 \mathrm{c}}$ from the last year \\
\hline QUS & Quantitative ultrasound \\
\hline SDS & Standard deviation score \\
\hline $\mathrm{SH}$ & Severe hypoglycaemia \\
\hline
\end{tabular}




\section{Introduction}

The influence of diabetes on bone status in young people has been described relatively recently [1]. In adults with type 1 diabetes, studies based on measurements at different skeletal sites have shown decreased bone mineral density (BMD) [1, 2]. The results and causative factors related to the hypothesised bone mineralisation diminution and bone disturbance in children and adolescents are more equivocal [3-9]. In adolescents with type 1 diabetes the influence of unsatisfactory metabolic control $[1,7,8]$, disease duration [6-8] and high insulin requirement [9] have been postulated.

Dual x-ray absorptiometry (DXA) remains a gold standard in bone densitometry. However, it may not be appropriate for assessing a maturing skeleton, as it allows only two-dimensional measurements and depends on bone size, therefore making the results potentially inaccurate [10]. Measurements made by quantitative ultrasound (QUS) are less influenced by bone size [11-13]. Importantly, when considering the paediatric population, no radiation is used and costs are relatively low. Prospective studies using QUS have revealed similar prognostic values for osteoporotic fractures as DXA in adults [10], and it has been shown to be similar to DXA in detecting low bone mineral status in young patients with fragility fractures $[14,15]$. Although phalangeal QUS seems to be a very promising tool in the assessment of skeletal status in children and adolescents, the use of QUS remains the subject of much controversy. These methods do not analyse bone mass, density and geometry separately, thereby giving only a general assessment of bone mineral status. The use of ultrasound methods to assess bone status in clinical practice is still limited, and no commonly accepted standards for QUS in either adults or children are available.

Adolescents comprise an interesting study group due to rapid developmental and pubertal changes. Many factors and pathophysiological changes influence final height and BMD. Early recognition of mineralisation disorders improves the likelihood that peak bone mass will be achieved in young people with diabetes. To address this question, we carried out a comparative assessment of QUS in adolescents with diabetes and controls. QUS measurements might become in the future a screening method of assessing bone status in young patients with diabetes.

\section{Methods}

Patients In the years 2006 and 2007 we invited all patients in the Diabetes Clinic in Katowice (Upper Silesia region), Poland, to participate in a skeletal QUS investigation. Out of 182 children, 99 met the inclusion criteria (type 1 diabetes duration at least 1 year, Tanner stage 2 or higher, age below 19 years). Patients with other chronic diseases or on medication known to alter bone metabolism, and those with other than type 1 diabetes, were excluded (coeliac disease: eight cases, thyroid diseases: ten cases, Maturity Onset Diabetes of the Young (MODY): one case).

Controls The control group consisted primarily of 874 healthy children from randomly chosen schools of the region of Upper Silesia, Poland, aged 9-19 years, who took part in screening QUS measurements conducted by Halaba and Pluskiewicz [16]. To each patient (group I) three healthy children were matched for age and sex, so that the final control population (group II) consisted of 297 children.

Clinical data Within both groups, data were collected according to a standardised questionnaire, including a history of chronic diseases, medication, fractures and activity levels. Patients with diabetes answered questions concerning the ongoing disease: date of diagnosis, number of episodes of severe hypoglycaemia ( $\mathrm{SH}$, defined as hypoglycaemia treated with a glucagon injection or glucose solution intravenously) and diabetes ketoacidosis (DKA, need for hospitalisation due to ketoacidosis), and present daily (24 h) insulin requirement (DIR). Height and weight were measured using standardised methods. BMI $\left(\mathrm{kg} / \mathrm{m}^{2}\right)$ was calculated for each individual, and weight, height and BMI standard deviation scores (SDS) were based on Polish normative data. Additionally for each patient the percentage of life with diabetes was calculated.

Pubertal development in the patient group was assessed by the children or their parents based on charts showing examples of pubertal stages according to Tanner and Whitehouse. Self-assessment is an accepted method of estimating pubertal development and correlates with assessment conducted by an endocrinologist [17]. In controls pubertal status was not assessed.

Laboratory investigations In all patients $\mathrm{HbA}_{1 \mathrm{c}}$ was measured on the day of the examination $\left(\mathrm{HbA}_{1 \mathrm{c}} \mathrm{D}\right)$. Previous $\mathrm{HbA} 1 \mathrm{c}$ results were extracted from the patient's clinical charts. Mean $\mathrm{HbA}_{1 \mathrm{c}}$ from the last year $\left(\mathrm{HbA}_{1 \mathrm{c}} \mathrm{Y}\right)$ and from the whole period of disease duration $\left(\mathrm{HbA}_{1 \mathrm{c}} \mathrm{T}\right)$ was calculated. Measurements were performed using high pressure liquid chromatography. For the subsequent analysis patients were divided into subgroups according to $\mathrm{HbA}_{1 \mathrm{c}}(\leq 7.0 \%$ and $>7.0 \%)$.

Bone measurements Quantitative ultrasound (QUS) was performed using a DMB Sonic 1200 device (IGEA, Capri, Italy). The device is equipped with two probes mounted on an electronic caliper. The emitter probe is positioned on the medial surface of the measured phalanx and the receiver probe is positioned on the lateral side of the phalanx. The time interval between emission and reception of the 
ultrasound signal is measured and expressed in $\mathrm{m} / \mathrm{s}$. The measurements of amplitude dependent speed of sound (AdSoS) were performed at the distal end of the proximal phalangeal diaphysis in the proximity of the condyles of proximal phalanxes II to $\mathrm{V}$ of the non-dominant hand and the mean of the results obtained for four fingers was taken into consideration. Acoustic coupling was achieved using a standard ultrasound contact gel. To normalise Ad-SoS for age and sex, a SDS was determined. It was calculated by means of a standard Z-score transformation using mean value and standard deviation appropriate for age and sex groups. Normative data for phalangeal quantitative ultrasound variables were published [12, 16, 18, 19]. The coefficient of variation (CV\%) for QUS measurements was $0.64 \%$. All measurements in the healthy children as well as in patients were performed by one experienced operator $(\mathrm{ZPH})$ and by means of the same device.

Bioethical policy Informed consent was obtained from all participants for the study. The study was approved by the institutional ethics committee.

Statistics Statistical analysis was performed with the $\mathrm{R}$ (www.bioconductor.org) software. For all the analysed variables descriptive statistics were calculated and appropriate figures were generated. Outlying values were detected using Tukey's criterion $(\operatorname{abs}(x)>\mathrm{Q} \pm 1.5 \times \mathrm{IQR})$, where IQR is the interquartile range, $\mathrm{Q}$ is the upper or lower quartile of the variable $x$. Distribution normality was estimated by Lilliefors' test. Bartlett statistic was used to verify the variance homogeneity hypothesis. In case of a non-normal distribution and/or lack of variance homogeneity, the hypothesis distribution concordance between groups was verified using the range non-parametric ANOVA Kruskal-Wallis test and Mann-Whitney $U$ test. For comparative analysis of normally distributed variables the standard ANOVA algorithm and Student's $t$ test were used. Depending on the distribution of the analysed continuous variables, Pearson's or Spearman's correlation coefficients were used to estimate the associations between two variables. Storey's multiple testing correction algorithm of the $p$ value was employed.

Discrete variables were analysed using $\chi^{2}$ test or G test. In each case a respective contingency table was constructed. The analysis results were considered to be significant at $p<0.05$. Values shown are mean \pm SD unless stated otherwise.

\section{Results}

The study population (group I) consisted of 99 children aged 9-18 years (49 female) with mean diabetes duration
$4.75 \pm 2.55$ years. The metabolic control of the patients was satisfactory: mean values of all three $\mathrm{HbA}_{1 \mathrm{c}}$ results were below $7.4 \%$. Positive history of DKA (at diagnosis or after) was provided by 24 patients (13 female) and at least one episode of SH was experienced by 23 adolescents (15 female). Table 1 shows the detailed characteristics of groups I and II.

Weight, height and BMI SDS were revealed to be higher in children with diabetes than in healthy controls $(p<0.001$ in each case). Higher BMI SDS in adolescent patients is mostly a result of the values observed for boys with diabetes.

Among patients with diabetes significant differences according to sex were observed (Table 1). In girls BMI SDS was lower $(p<0.001)$ than in boys, although no differences in weight and height SDS were shown. All considered $\mathrm{HbA}_{1 \mathrm{c}}$ values were lower in girls than in boys $(p<0.05)$. The duration of diabetes and percentage of life with diabetes were higher in female patients, but the difference did not reach statistical significance.

A similar comparative analysis was performed for the subgroups according to metabolic control (Table 2). The stratification $\mathrm{HbA}_{1 \mathrm{c}}$ value $7.0 \%$ was chosen as a compromise between the recommendations of the Polish Diabetes Association $\left(\mathrm{HbA}_{1 \mathrm{c}} \leq 6.5 \%\right)$ [20] and the International Society for Pediatric and Adolescent Diabetes guidelines $\left(\mathrm{HbA}_{1 \mathrm{c}}<7.5 \%\right)$ [21]. Patients with $\mathrm{HbA}_{1 \mathrm{c}} \mathrm{T},-\mathrm{Y}$ and $-\mathrm{D}$ $\leq 7 \%$ had significantly lower BMI SDS $(p<0.001$ in all cases) than the corresponding subgroups with less satisfactory glycaemic control. In adolescents with $\mathrm{HbA}_{1 \mathrm{c}} \mathrm{T}$ and $-\mathrm{Y} \leq 7 \%$, a higher SDS for height was observed (both $p<0.05$ ) compared with those with $\mathrm{HbA}_{1 \mathrm{c}} \mathrm{T}$ and $-\mathrm{Y}>7 \%$. The analysis of the remaining variables (including DIR, diabetes duration and percentage of life with diabetes) did not show any other significant differences for $\mathrm{HbA}_{1 \mathrm{c}} \mathrm{T}, \mathrm{HbA}_{1 \mathrm{c}} \mathrm{Y}$ and $\mathrm{HbA}_{1 \mathrm{c}} \mathrm{D}$ subgroups.

Comparison of the study groups revealed significantly lower Ad-SoS SDS in patients $(-0.34,95 \%$ CI -0.57 , $-0.11)$ vs controls $(-0.03,95 \%$ CI $-0.15,0.08 ; p<0.05$; Fig. 1). In addition, significantly lower Ad-SoS SDS was observed for adolescents with $\mathrm{HbA}_{1 \mathrm{c}} \mathrm{D}>7.0 \%$ than in patients with $\mathrm{HbA}_{1 \mathrm{c}} \mathrm{D} \leq 7 \%(0.08$ [95\% CI $-0.22,0.37]$ vs -0.47 [95\% CI $-0.79,-0.15] ; p<0.05$ ). No significant differences in QUS measurements for $\mathrm{HbA}_{1 \mathrm{c}} \mathrm{T}$ and $\mathrm{HbA}_{1 \mathrm{c}} \mathrm{Y}$ subgroups were shown. ANOVA tests revealed that metabolic control subgroups and group II are different. Figure 2 shows Ad-SoS SDS values of $\mathrm{HbA}_{1 \mathrm{c}} \mathrm{Y}$ subgroups and healthy adolescents.

We observed no influence of sex on Ad-SoS SDS. No impact of either positive DKA or SH history (respectively: $-0.64[95 \%$ CI $-1.21,0.08]$ vs -0.53 [85\% CI -0.84 , $-0.21]$ and $-0.72[95 \% \mathrm{CI}-1.23,-0.20]$ vs -0.60 [95\% CI $-0.89,-0.31]$; both $p>0.05$ ) was found. From 
Table 1 The characteristics of the study and control groups

\begin{tabular}{|c|c|c|c|c|c|c|}
\hline \multirow[t]{2}{*}{ Variable } & \multicolumn{3}{|l|}{ Patients } & \multicolumn{3}{|l|}{ Controls } \\
\hline & Girls & Boys & Total & Girls & Boys & Total \\
\hline$n$ & 49 & 50 & 99 & 147 & 150 & 297 \\
\hline Age (years) & $13.9 \pm 2.7$ & $14.7 \pm 2.3$ & $14.3 \pm 2.5$ & $13.9 \pm 2.5$ & $14.7 \pm 2.3$ & $14.3 \pm 2.4$ \\
\hline Weight SDS & $\begin{array}{l}0.29 \pm 0.92 \\
(-0.22,0.30)\end{array}$ & $\begin{array}{l}0.16 \pm 0.89 \\
(-0.22,0.27)\end{array}$ & $\begin{array}{l}0.22 \pm 0.90^{\mathrm{a}} \\
(0.04,0.40)\end{array}$ & $\begin{array}{l}-0.09 \pm 0.74 \\
(-0.21,0.03)\end{array}$ & $\begin{array}{l}-0.30 \pm 0.74 \\
(-0.42,-0.18)\end{array}$ & $\begin{array}{l}-0.20 \pm 0.75 \\
(-0.28,-0.11)\end{array}$ \\
\hline Height SDS & $\begin{array}{l}0.43 \pm 1.03 \\
(0.17,0.70)\end{array}$ & $\begin{array}{l}0.10 \pm 0.79 \\
(-0.11,0.31)\end{array}$ & $\begin{array}{l}0.31 \pm 0.93^{\mathrm{a}} \\
(0.12,0.49)\end{array}$ & $\begin{array}{l}-0.01 \pm 1.10 \\
(-0.19,0.17)\end{array}$ & $\begin{array}{l}-0.22 \pm 0.86 \\
(-0.36,-0.08)\end{array}$ & $\begin{array}{l}-0.12 \pm 0.99 \\
(-0.23,-0.00)\end{array}$ \\
\hline BMI SDS & $\begin{array}{l}-0.03 \pm 0.98^{\mathrm{b}} \\
(-0.31,0.25)\end{array}$ & $\begin{array}{l}1.65 \pm 1.26 \\
(1.29,2.00)\end{array}$ & $\begin{array}{l}0.82 \pm 1.41^{\mathrm{a}} \\
(0.54,1.10)\end{array}$ & $\begin{array}{l}-0.07 \pm 0.77 \\
(-0.13,-0.02)\end{array}$ & $\begin{array}{l}-0.08 \pm 0.98 \\
(-0.16,-0.03)\end{array}$ & $\begin{array}{l}-0.06 \pm 0.88 \\
(-0.16,0.04)\end{array}$ \\
\hline Duration (years) & $\begin{array}{l}5.0 \pm 2.6 \\
(4.4,5.7)\end{array}$ & $\begin{array}{l}4.5 \pm 2.5 \\
(3.8,5.1)\end{array}$ & $\begin{array}{l}4.8 \pm 2.6 \\
(2.9,6.1)\end{array}$ & & & \\
\hline$\%$ of life with T1DM & $\begin{array}{l}36.7 \pm 18.9 \\
(31.8,41.6)\end{array}$ & $\begin{array}{l}30.7 \pm 15.9 \\
(26.5,34.9)\end{array}$ & $\begin{array}{l}33.8 \pm 17.7 \\
(19.9,43.3)\end{array}$ & & & \\
\hline DIR (U kg $\left.\mathrm{kg}^{-1} 24 \mathrm{~h}^{-1}\right)$ & $\begin{array}{l}0.82 \pm 0.27 \\
(0.74,0.89)\end{array}$ & $\begin{array}{l}0.82 \pm 0.26 \\
(0.75,0.89)\end{array}$ & $\begin{array}{l}0.82 \pm 0.26 \\
(0.67,0.98)\end{array}$ & & & \\
\hline $\mathrm{HbA}_{1 \mathrm{c}} \mathrm{D}(\%)$ & $\begin{array}{l}7.17 \pm 1.54^{\mathrm{c}} \\
(6.70,7.63)\end{array}$ & $\begin{array}{l}7.53 \pm 1.15 \\
(7.20,7.87)\end{array}$ & $\begin{array}{l}7.38 \pm 1.32 \\
(6.50,8.10)\end{array}$ & & & \\
\hline $\mathrm{HbA}_{1 \mathrm{c}} \mathrm{Y}(\%)$ & $\begin{array}{l}6.94 \pm 1.43^{c} \\
(6.45,7.44)\end{array}$ & $\begin{array}{l}7.36 \pm 1.25 \\
(6.96,7.76)\end{array}$ & $\begin{array}{l}7.16 \pm 1.28 \\
(6.40,7.67)\end{array}$ & & & \\
\hline $\mathrm{HbA}_{1 \mathrm{c}} \mathrm{T}(\%)$ & $\begin{array}{l}7.04 \pm 1.02^{\mathrm{c}} \\
(6.68,7.39)\end{array}$ & $\begin{array}{l}7.39 \pm 0.88 \\
(7.11,7.67)\end{array}$ & $\begin{array}{l}7.23 \pm 0.93 \\
(6.63,7.64)\end{array}$ & & & \\
\hline
\end{tabular}

Data are mean $\pm \mathrm{SD}$ and $(95 \% \mathrm{CI})$ except age

${ }^{\mathrm{a}} p<0.001$ vs healthy adolescents; ${ }^{\mathrm{b}} p<0.001$ vs male patients; ${ }^{\mathrm{c}} p<0.05$ vs male patients

T1DM, type 1 diabetes mellitus

Table 2 Comparison of $\mathrm{HbA}_{1 \mathrm{c}}$ subgroups

\begin{tabular}{|c|c|c|c|c|c|c|}
\hline \multirow[t]{2}{*}{ Variable } & \multicolumn{2}{|l|}{$\mathrm{HbA}_{1 \mathrm{c}} \mathrm{D}(\%)$} & \multicolumn{2}{|l|}{$\mathrm{HbA}_{1 \mathrm{c}} \mathrm{Y}(\%)$} & \multicolumn{2}{|l|}{$\mathrm{HbA}_{1 \mathrm{c}} \mathrm{T}(\%)$} \\
\hline & $\leq 7$ & $>7$ & $\leq 7$ & $>7$ & $\leq 7$ & $>7$ \\
\hline$n$ & 45 & 48 & 41 & 33 & 36 & 38 \\
\hline Female/male (\%) & $63 / 37$ & $35 / 65$ & $56 / 44$ & $33 / 67$ & $58 / 42$ & $34 / 66$ \\
\hline Weight SDS & $\begin{array}{l}-0.03 \\
(-0.27,0.21)\end{array}$ & $\begin{array}{l}0.26 \\
(0.02,0.51)\end{array}$ & $\begin{array}{l}0.11 \\
(-0.11,0.34)\end{array}$ & $\begin{array}{l}0.14 \\
(-0.17,0.45)\end{array}$ & $\begin{array}{l}0.59 \\
(0.28,0.89)\end{array}$ & $\begin{array}{l}0.05 \\
(-0.17,0.27)\end{array}$ \\
\hline Height SDS & $\begin{array}{l}0.37 \\
(0.11,0.62)\end{array}$ & $\begin{array}{l}0.10 \\
(-0.14,0.33)\end{array}$ & $\begin{array}{l}0.59 \\
(0.31,0.86)\end{array}$ & $\begin{array}{l}-0.03^{\mathrm{a}} \\
(-0.26,0.20)\end{array}$ & $\begin{array}{l}0.59 \\
(0.28,0.89)\end{array}$ & $\begin{array}{l}0.05^{\mathrm{a}} \\
(-0.17,0.27)\end{array}$ \\
\hline BMI SDS & $\begin{array}{l}0.20 \\
(-0.10,0.49)\end{array}$ & $\begin{array}{l}1.12^{\mathrm{b}} \\
(0.74,1.51)\end{array}$ & $\begin{array}{l}0.36 \\
(0.05,0.66)\end{array}$ & $\begin{array}{l}1.07^{\mathrm{b}} \\
(0.62,1.51)\end{array}$ & $\begin{array}{l}0.33 \\
(-0.05,0.70)\end{array}$ & $\begin{array}{l}1.00^{\mathrm{b}} \\
(0.63,1.37)\end{array}$ \\
\hline Duration (years) & $\begin{array}{l}4.4 \\
(3.9,5.0)\end{array}$ & $\begin{array}{l}5.1 \\
(4.3,5.8)\end{array}$ & $\begin{array}{l}4.2 \\
(3.6,4.9)\end{array}$ & $\begin{array}{l}5.2 \\
(4.3,6.0)\end{array}$ & $\begin{array}{l}4.4 \\
(3.6,5.1)\end{array}$ & $\begin{array}{l}4.9 \\
(4.1,5.7)\end{array}$ \\
\hline$\%$ of life with T1DM & $\begin{array}{l}32.1 \\
(28.1,36.2)\end{array}$ & $\begin{array}{l}35.4 \\
(30.3,40.4)\end{array}$ & $\begin{array}{l}30.3 \\
(25.4,35.2)\end{array}$ & $\begin{array}{l}36.0 \\
(30.7,41.2)\end{array}$ & $\begin{array}{l}30.7 \\
(25.7,35.6)\end{array}$ & $\begin{array}{l}34.9 \\
(29.7,40.1)\end{array}$ \\
\hline DIR (U kg $\left.{ }^{-1} 24 \mathrm{~h}^{-1}\right)$ & $\begin{array}{l}0.85 \\
(0.78,0.93)\end{array}$ & $\begin{array}{l}0.79 \\
(0.71,0.86)\end{array}$ & $\begin{array}{l}0.78 \\
(0.71,0.86)\end{array}$ & $\begin{array}{l}0.83 \\
(0.73,0.93)\end{array}$ & $\begin{array}{l}0.80 \\
(0.71,0.88)\end{array}$ & $\begin{array}{l}0.81 \\
(0.72,0.90)\end{array}$ \\
\hline
\end{tabular}

Data are mean $(95 \% \mathrm{CI})$

Significantly different from respective $\mathrm{HbA}_{1 \mathrm{c}} \leq 7.0 \%$ group: ${ }^{\mathrm{a}} p<0.05 ;{ }^{\mathrm{b}} p<0.001$

T1DM, type 1 diabetes mellitus 


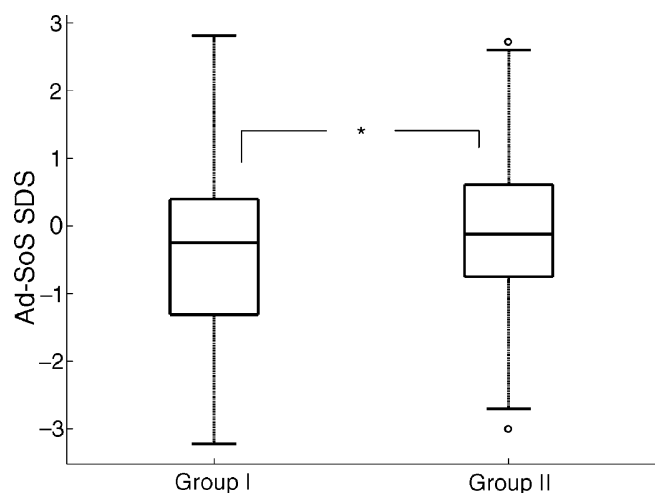

Fig. 1 Comparison of patients (group I) and controls (group II) according to Ad-SoS SDS. ${ }^{*} p<0.05$. Small circle symbol denotes the outlier

all analysed variables only significant negative correlations between BMI SDS $(r=-0.24, p<0.05)$ as well as $\mathrm{HbA}_{1 \mathrm{c}} \mathrm{D}$ $(r=-0.22, p<0.05)$ and Ad-SoS SDS were revealed. A significant positive correlation was observed between height SDS and Ad-SoS SDS $(r=0.21, p<0.05)$.

Based on the former single variable analysis and review of previous studies, variables with potential influence on Ad-SoS SDS were chosen. Two different multivariable stepwise regression starting models were constructed. The first one included BMI SDS and the second one was based on weight and height SDS. After comparing both models (Bayesian information criterion [BIC] 855.27 and 850.37, respectively) we decided to employ the first model in further analyses. The analysis was expanded by following clinical factors: age, $\mathrm{HbA}_{1 \mathrm{c}} \mathrm{T}$, diabetes duration and DIR. The final model:

Ad-SoS SDS $=1.42-0.24 \times$ BMI SDS $-0.21 \times \mathrm{HbA}_{1 \mathrm{c}} \mathrm{T}$

revealed that Ad-SoS SDS was negatively related to BMI SDS (0.2446 decrease per unit, $p=0.017)$. $\mathrm{HbA}_{1 \mathrm{c}} \mathrm{T}$ was a correction factor $(0.2128$ decrease per unit, $p=0.119)$ for the influence of BMI SDS on Ad-SoS SDS. This indicates that in adolescents with diabetes long-term metabolic control is an additional factor moderating the influence of BMI SDS on bone status.

\section{Discussion}

This study highlights a significant difference in bone status assessed by means of Ad-SoS between adolescents with diabetes and healthy controls. Bone status of patients was significantly worse, although they were characterised by greater weight, height and BMI SDS-factors that usually correlate positively with bone mineral density. Bone dimensions may affect QUS measurements. The positive correla- tion between bone size and ultrasound variables exists because body height influences the mechanical forces applied to the skeleton and subsequently bone strength. It seems, however, that QUS techniques - especially Ad-SoS - may be less affected by bone size than DXA measurements [11-13].

A negative influence of type 1 diabetes on bone has been observed in a number of case-control studies conducted in adults $[2,22]$ as well as in children and adolescents $[1,4,6$, 23-25], where peripheral and axial DXA and QCT were employed. It has been suggested that observed differences in adults may result from mineralisation disorders, which operate during rapid skeletal development in puberty.

On the other hand, some studies have not confirmed a significant decrease in densitometric variables in young patients with diabetes $[5,26,27]$. However, certain of them indicate the presence of discrete bone mineralisation disorders, such as a decrease of bone formation markers and increase of bone resorption markers [28] or lower bone mineral acquisition $[5,26]$.

The present study was based on QUS, which has been found to correlate with DXA results in adults [10]. It needs to be underlined that QUS and DXA do not measure identical properties of bone tissue. QUS variables are influenced not only by bone density, but also by bone structure and composition. We have found that only a few other authors have used the QUS method to estimate bone status in children with type 1 diabetes $[6,8,29,30]$ and our pilot study is the only one to have compared QUS results with a healthy control group [29].

Our analysis showed that Ad-SoS SDS is negatively correlated with $\mathrm{HbA}_{1 \mathrm{c}} \mathrm{D}$, and bone quality was also found to be influenced by $\mathrm{HbA}_{1 \mathrm{c}} \mathrm{T}$ and BMI SDS. Our study did not reveal any correlation between bone status of adolescents with type 1 diabetes and other analysed factors.

Damilakis et al., in an observation of 30 patients with uncomplicated type 1 diabetes aged $11.3 \pm 4.6$ years [6], did

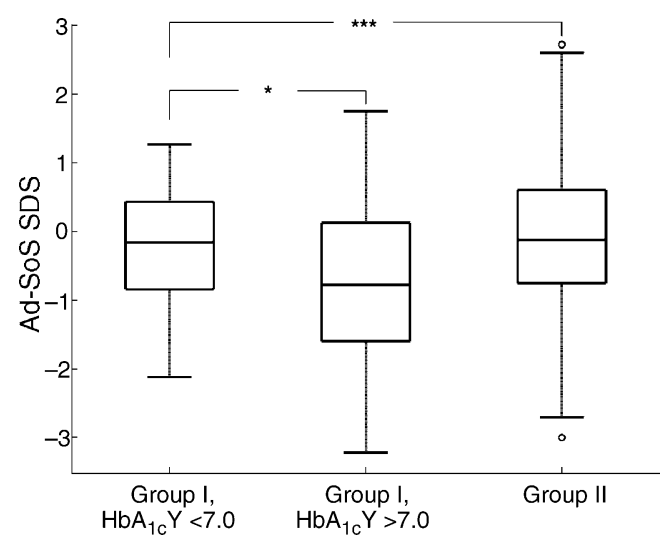

Fig. 2 Ad-SOS SDS in patients divided according to $\mathrm{HbA}_{1 \mathrm{c}} \mathrm{Y}$ (group I) and in healthy adolescents (group II). ${ }^{*} p<0.05, * * * p<0.001$ Small circle symbol denotes the outlier 
not reveal any correlation of $\mathrm{HbA}_{1 \mathrm{c}} \mathrm{T}$ and QUS results. However, the authors described a significant influence of diabetes duration on bone status, but their patient group was smaller and characterised by longer diabetes duration $(6.1 \pm$ 4.2 years). The discrepancies from our findings could be also a result of a different measurement site: radial and tibial QUS measurements. This suggestion may be supported by our pilot study [29].

Both studies by Valerio et al., presenting phalangeal QUS results, revealed significant negative correlation between metabolic control and Ad-SoS SDS [8, 30]. In 86 patients, aged $11.9 \pm 14.4$ years (similar to our study group), relationships between $\mathrm{HbA}_{1 \mathrm{c}} \mathrm{D}$ and $\mathrm{Y}$ and bone status were reported [8]. The latter study again showed a correlation of Ad-SoS SDS and $\mathrm{HbA}_{1 \mathrm{c}} \mathrm{Y}$ in patients with uncomplicated type 1 diabetes, without any other diseases [30].

Additionally, the first analysis of these authors showed a significant influence of diabetes duration (mean 4.3 years) on bone status [8]. The inconsistency with our findings may result from the different pubertal status of the children composing their study group.

No differences of QUS values between sexes were observed in any of the above mentioned studies. The influence of DIR and BMI SDS on QUS measurements was assessed only in one publication [8]. The findings regarding DIR are in agreement with our results. Other authors did not observe any influence of BMI, but the values were expressed in percentiles and therefore the results are difficult to compare.

Our study has some limitations. The nature of bone changes during the course of diabetes cannot be evaluated as in a prospective study, but further studies might show changes over time if duration of diabetes and metabolic control are influential. Only one skeletal site was measured, and bone densitometry measurements were not performed. Another drawback of the study is the fact that differences in pubertal stages were not taken into account. However, one ought to take into consideration that the aim of the study was not the estimation of relationships between sexual maturity and bone status. We consider that randomly selected controls reliably express sexual maturation of the regional child and adolescent population.

The large study and control group, both belonging to the homogeneous white population of one region of Poland, and the relatively good metabolic control of the patients indicate the power of the study.

In conclusion, bone status assessed by means of amplitude dependent speed of sound QUS in adolescents with type 1 diabetes significantly differs from that observed in a healthy population. Lower QUS variables observed in pubertal patients are related to long-term metabolic control. Anthropometric factors are also associated with bone status. It is likely, therefore, that optimising glycaemic control over the years of childhood diabetes may help prevent the decrease of bone quality.

Acknowledgements We would like to thank the Association for Children with Diabetes, Katowice, Poland, for their support and cooperation regarding the study. The authors thank Dr Peter Swift, Children's Hospital, Leicester Royal Infirmary, UK, for his essential comments and English correction. The results of the study were partially presented during the ISPAD 2008 Annual Meeting in Durban, South Africa. This study was partially financed by KBN project NN519579938 and the Association for Children with Diabetes, Katowice, Poland.

Duality of interest The authors declare that there is no duality of interest associated with this manuscript.

\section{References}

1. Heap J, Murray MA, Miller SC, Jalili T, Moyer-Mileur LJ (2004) Alterations in bone characteristics associated with glycemic control in adolescents with type 1 diabetes mellitus. J Pediatr 144:56-62

2. Rakic V, Davis WA, Chubb SAP, Islam FMA, Prince RL, Davis TME (2006) Bone mineral density and its determinants in diabetes: the Fremantle Diabetes Study. Diabetologia 49:863-871

3. Mastrandrea LD, Wactawski-Wende J, Donahue RP, Hovey KM, Clark A, Quattrin T (2008) Young women with type 1 diabetes have lower bone mineral density that persists over time. Diab Care 31:1729-1735

4. Saha MT, Sievänen H, Salo MK, Tulokas S, Saha HH (2009) Bone mass and structure in adolescents with type 1 diabetes compared to healthy peers. Osteoporos Int 20:1401-1406

5. Vazquez Gamez MA, Marin Perez JM, Montoya Garcia MJ, Moruno Garcia RM, Argüelles Martin F, Perez Cano R (2008) Evolution of bone mass in children and adolescents with type 1 diabetes mellitus. Med Clin (Barc) 130:526-530 (article in Spanish)

6. Damilakis J, Galanakis E, Mamoulakis D, Sbyrakis S, Gourtsoyiannis N (2004) Quantitative ultrasound measurements in children and adolescents with: type 1 diabetes. Calcif Tissue Int 74:424-428

7. Camurdan MO, Ciaz P, Bideci A, Demirel F (2007) Role of hemoglobin A1c, duration and puberty on bone mineral density in diabetic children. Pediatr Int 49:645-651

8. Valerio G, del Puente A, Buono P et al (2004) Quantitative ultrasound of proximal phalanxes in patients with type 1 diabetes mellitus. Diab Res Clin Pract 64:161-166

9. Léger J, Marinovic D, Alberti C et al (2006) Lower bone mineral content in children with type 1 diabetes mellitus is linked to female sex, low insulin-like growth factor type I levels and high insulin requirement. J Clin Endocrinol Metab 91:3947-3953

10. Baroncelli GI (2008) Quantitative ultrasound methods to assess bone mineral status in children: technical characteristics, performance and clinical application. Pediatr Res 63:220-228

11. Barkmann R, Lusse S, Stampa B, Sakata S, Heller M, Gluer CC (2000) Assessment of the geometry of human finger phalanges using quantitative ultrasound in vivo. Osteoporos Int 11:745-755

12. Baroncelli GI, Federico G, Bertelloni S, de Terlizzi F, Cadossi R, Saggese G (2001) Bone quality assessment by quantitative ultrasound of proximal phalanxes of the hand in healthy subjects aged 3-21 years. Pediatr Res 49:713-718

13. Guglielmi G, Njeh CF, de Terlizzi F et al (2003) Phalangeal quantitative ultrasound, phalangeal morphometric variables, and vertebral fracture discrimination. Calcif Tissue Int 72:469-477 
14. Baroncelli GI, Federico G, Bertelloni S et al (2003) Assessment of bone quality by quantitative ultrasound of proximal phalanges of the hand and fracture rate in children and adolescents with bone and mineral disorders. Pediatr Res 54:125-136

15. Fielding KT, Nix DA, Bachrach LK (2003) Comparison of calcaneus ultrasound and dual X-ray absorptiometry in children at risk of osteopenia. J Clin Densitom 6:7-15

16. Halaba ZP, Pluskiewicz W (2004) Quantitative ultrasound in the assessment of skeletal status in children and adolescents. Ultrasound Med Biol 30:239-243

17. Duke PM, Litt IF, Gross RT (1980) Adolescents' self-assessment of sexual maturation. Pediatrics 66:918-920

18. Halaba Z, Pluskiewicz W (1997) The assessment of development of bone mass in children by quantitative ultrasound through the proximal phalanxes of the hand. Ultrasound Med Biol 23:13311335

19. Barkmann R, Rohrschneider W, Vierling M et al (2002) German pediatric reference data for quantitative ultrasound of finger phalanges. Osteoporos Int 13:55-61

20. Polish Diabetes Association (2009) Clinical recommendations for the treatment of patients with diabetes (article in Polish). Available from www.cukrzyca.info.pl/UserAttachments/File/DDiK\%20zale cenia\%20PTD\%202009_calosc.pdf, accessed 30 December 2009

21. Rewers M, Pihoker C, Donaghue K, Hanas R, Swift P, Klingensmith GJ (2007) Assessment and monitoring of glycemic control in children and adolescents with diabetes. Pediatr Diab 8:408-418

22. Ingberg CM, Palmér M, Aman J, Arvidsson B, Schvarcz E, Berne C (2004) Body composition and bone mineral density in long-standing type 1 diabetes. J Intern Med 255:392-398
23. Heilman K, Zilmer M, Zilmer K, Tillmann V (2009) Lower bone mineral density in children with type 1 diabetes is associated with poor glycemic control and higher serum ICAM-1 and urinary isoprostane levels. J Bone Miner Metab 27:598-604

24. Hadjidakis DJ, Raptis AE, Sfakianakis M, Mylonakis A, Raptis SA (2006) Bone mineral density of both genders in type 1 diabetes according to bone composition. J Diabetes its Complicat 20:302-307

25. Moyer-Mileur LJ, Slater H, Jordan KC, Murray MA (2008) IGF-1 and IGF-binding proteins and bone mass, geometry, and strength: relation to metabolic control in adolescent girls with type 1 diabetes. J Bone Miner Res 23:1884-1891

26. Salvatoni A, Mancassola G, Biasoli R et al (2004) Bone mineral density in diabetic children and adolescents: a follow up study. Bone 34:900-904

27. Brandao FR, Vicente EJ, Daltro CH, Sacramento M, Moreira A, Adan L (2007) Bone metabolism is linked to disease duration and metabolic control in type 1 diabetes mellitus. Diab Res Clin Pract 78:334-339

28. Karagüzel G, Akçurin S, Ozdem S, Boz A, Bircan I (2006) Bone mineral density and alterations of bone metabolism in children and adolescents with type 1 diabetes mellitus. J Pediatr Endocrinol Metab 19:805-814

29. Halaba ZP, Chobot A, Haffke A et al (2008) The assessment of skeletal status in children and adolescents with type 1 diabetes by quantitative ultrasound of the hand phalanges. A pilot study. Endokrynologia Pediatryczna 7:21-26 (article in Polish)

30. Valerio G, Spadaro R, Iafusco D et al (2008) The influence of gluten free diet on quantitative ultrasound of proximal phalanxes in children and adolescents with type 1 diabetes mellitus and celiac disease. Bone 43:322-326 